ФIНАНСИ. БАНКІВСЬКА СПРАВА

UDC 657.471 .1

V. S. Nitsenko, Doctor of Economic Sciences, Associate Professor, V. S. Mukoviz, Candidate of Economic Sciences, Associate Professor, O. M. Sharapa, Candidate of Economic Sciences

\section{ACCOUNTING OF TRANSACTION EXPENSES OF ECONOMIC ENTITIES}

Urgency of the research. Transaction expenses are non-visible, non-obvious costs. They are hidden between other overhead costs of the enterprise and expenses of the period. But, despite the invisibility, transaction expenses can have a significant impact on the costs level and financial results of the enterprise, as well as on unit cost and ultimately, on the price competitiveness.

Target setting. Currently, basis for managerial decisions of enterprise is formed by accounting information. Respectively, to ensure economics growth and crisis overcome, accountancy impartiality, completeness and reliability of financial reports are key elements that needed. Taking into account contradictory socio-economic transformations and the most valuable global trends and that is based on institutional economic theory, a thorough study of the identifying process of transaction expenses, is required.

Analysis of recent researches and publications. An issue of transaction expenses is relatively new to our country's scientific scope. This question is researched by such scientists as S. Arkhiperev, M. Danko, O. Kantsurov, A. Chukhno and some others in theirs work.

Uninvestigated parts of general matters defining Incurrence of the transaction expenses of the enterprise requires comprehensive scientific research as their factors are still unknown at the scientific level.

The research objective. To reveal the essence and causes of incurred transaction expenses at the enterprise.

The statement of basic materials. This article only reveals methodological features of some transaction expenses, those are possible to detect and estimate through accounting, the ones actually incurred costs recorded in primary documents and disclosed in the financial statements, but are not classified as transaction costs.

Conclusions. The main factors of transaction expenses occurrence are uncertain behavior of subjects of economic relations, pursuance of established social norms, ensuring rights and interests implementation and protection of subjects of economic relations and society. Reasons for transaction expenses occurrence predetermined by institutional factors but their extent formed considering market factors.

Удк 657.471.1

В. С. Ніценко, д. е. н., доцент,

В. С. Муковіз, к. е. н., доцент,

O. M. Шарапа, к. е. н.

\section{ОБЛІК ТРАНСАКЦІЙНИХ ВИТРАТ СУБ'ЄКТІВ ГОСПОДАРЮВАННЯ}

Актуальність теми дослідження. Трансакційні витрати є невидимими, неочевидними витратами. Вони сховані між іншими накладними витратами підприємства та витратами періоду. Але, незважаючи на невидимість, трансакційні витрати можуть здійснювати суттєвий вплив на рівень витрат та фрінансові результати підприємства, на собівартість одиниці продукиії $i$, зрештою, на цінову конкурентоспроможність підприємства.

Постановка проблеми. На даний час інфрормація сфрормована бухгалтерським обліком, $\epsilon$ основою прийняття рішень, пов'язаних 3 управлінням підприємством. Відповідно неупередженість бухгалтерського обліку, повнота та достовірність фрінансової звітності мають вагоме значення для забезпечення подолання кризових явищ та економічного зростання. Iз урахуванням суперечливих соціальноекономічних перетворень та найважливіших світових тенденцій потребує грунтовного вивчення процес ідентифрікації трансакційних витрат, виходячи із інституиіональної економічної теорії.

Аналіз останніх досліджень i публікацій. Питання виникнення трансакційних витрат відносно нове у вітчизняному науковому просторі. Цьому питанню у своїх працях приділяють увагу такі вчені як С. Архієреєв, М. Данько, О.Канцуров, А. Чухно та ін.

Виділення недосліджених частин загальноі проблеми. На науковому рівні досі не встановлено чинників понесення трансакційних витрат підприємства, що потребує проведення всебічних наукових досліджень.

Постановка завдання. Розкрити суть та причини понесення трансакційних витрат на підприємстві.

Виклад основного матеріалу. У статmі розкрито методологічні особливості лише частини трансакційних витрат - тих, які можна виявити й оцінити методом бухаалтерського обліку, тобто фактично понесені витрати, що фріксуються в первинних документах $i$ відображаються $е$ бухгалтерському обліку та розкриваються у фінансовій звітності, але при цьому не класифікуються як трансакційні витрати.

Висновки. Основними чинниками понесення трансакційних витрат $є$ невизначеність поведінки суб'єктів економічних відносин, виконання встановлених соціальних норм, забезпечення реалізації i захисту прав та інтересів суб'єктів економічних відносин i суспільства. Причини понесення трансакційних витрат зумовлені інституціональними чинниками, проте їх обсяа формується з урахуванням ринкових чинників. 


\section{ФIНАНСИ. БАНКІВСЬКА СПРАВА}

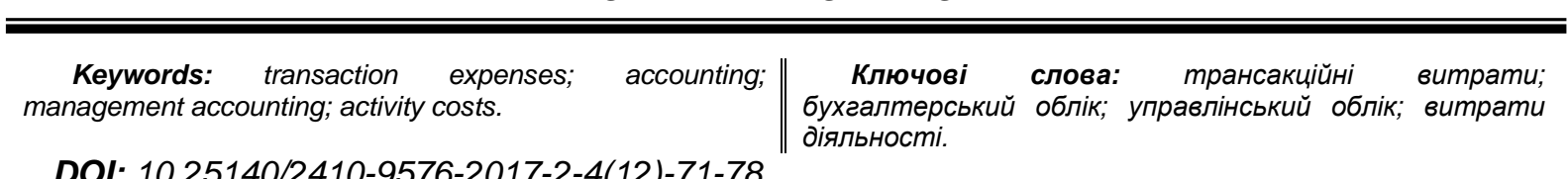

DOI: 10.25140/2410-9576-2017-2-4(12)-71-78

Urgency of the research. New to Ukraine market infrastructure organisations appearance and further labor division led to necessity of an economy reform in Ukraine based on the principles and main provisions of institutionalism. Companies intensify its activities in the supply and marketing of products and services under the transformational economy. The expansion of enterprise's business relations positively affects their effectiveness on one hand but in the other hand causes an increase in their transaction costs. Transaction expenses are non-visible, non-obvious costs. They are hidden between other overhead costs of the enterprise and expenses of the period. But, despite the invisibility, transaction expenses can have a significant impact on the costs level and financial results of the enterprise, as well as on unit cost and, ultimately, on the price competitiveness.

Target setting. To insure stable development effective information management systems must be implemented to form sufficient accounting and analytical information of appropriate quality level and utility to its users. Information system provides activities expansion, development strategy implementation, internal control and analysis system formation together with investments initiation.

Currently, basis for managerial decisions of enterprise is formed by accounting information. Respectively, to ensure economics growth and crisis overcome, accountancy impartiality, completeness and reliability of financial reports are key elements that needed. Taking into account contradictory socio-economic transformations and the most valuable global trends and that is based on institutional economic theory, a thorough study of the identifying process of transaction expenses, is required.

Actual scientific research and issues analysis. Transaction expenses as a concept are quite new for Ukrainian scientific scope. Even though polemics about the essence of transaction expenses and it occurrence source do not subside until now, it grabbed the attention of domestic scientists from the moment of it insulation. B. Kvasnyukta and S. Kireev in the section of their monograph "Model Transformation of Ukrainian economy (ideology, contradictions, perspectives)" expressed a quite an opinion... "in the Ukrainian scientific literature, the institutional sectors functioning of the economy its theory and practice have not been actually studied". The issues of information support implementation of existing procedures to research transaction expenses at the enterprise level are not sufficiently explored at the present time.

Specific questions of transaction expenses are researched by Ukrainian scientists. For instance, the peculiarities of the enterprise transaction costs formation, theoretical and methodological aspects of its definition, and empirical analysis of its behavior were investigated in their work by L. Bazalieva, M. Danko, O. Kantsurov, R. Pustovit. In the mentioned scientific studies an attempt to draw the attention of domestic researchers to the existence of transaction expenses problem was made. There are a few Ukrainian researchers that systematically study the problem of transaction expenses S. Borkireev, I. Buleev, N. Bryukhovetska and others.

Problems with transaction expenses at the enterprise level stay untouched.

After all, this study should be carried out not only at the macro level, but also at the enterprise level, as this would allow to solve the main issue in the study of transaction costs - what exactly is most expensive during transactions.

Uninvestigated parts of general matters defining. Incurrence of the transaction expenses of the enterprise requires comprehensive scientific research as their factors are still unknown at the scientific level.

The research objective. To reveal the essence and causes of incurred transaction expenses at the enterprise.

The statement of basic materials. One of the main principles of institutionalism is the recognition that transaction expenses do exist and affect decisions of the economic entities. To date, transaction costs remain, in our opinion, the most uncertain category, even though recently in the World and in Ukraine great attention is paid to study transaction expenses issues. 


\section{ФIНАНСИ. БАНКІВСЬКА СПРАВА}

The concept of "transaction" has become categorically important for researchers of institutionalism among those Nobel Prize laureate in Economics R. Coase, who believed that transaction expenses incur due to the fact that buyers and sellers have to find each other; buyers should research what vendors can offer them, and sellers - what buyers want to buy; both parties must study prices that would agree with other party and persuade to conduct transactions, the parties must negotiate, conclude and execute contracts. The emergence of a company - as a business unit - he saw as a result of an attempt to save on transaction expenses [1].

Further more, the world-famous scientist $\mathrm{O}$. Williamson defines transaction expenses as "the cost of opportunistic behavior" [2], and K. Dalman considers transaction expenses as "the costs of collecting and processing information, costs of negotiation and decision-making, control costs and legal protection of contract performance" [3, p. 417].

Based on the institutional theory, the transformation costs and transaction expenses affect the behavior of enterprises as economic entities and their management decisions [4].

Expenses of economic entities are recognised as expenses of a certain period at the same time as recognising the income for which they are incurred. Costs that can not be directly related to the income of a particular period are reflected in the expense of the reporting period in which they were incurred [5].

Earned income can be compared with consumption costs and transformation of production factors, which form the cost of products sold (works, services).

In particular, it includes the production cost of products (works, services) sold during the reporting period, which includes direct material expenses, direct labor costs, other direct costs, variable and fixed as well as undistributed permanent generic production costs together with excess production costs. It can be asserted that the cost of sold products (works, services) is the transformational costs of operating activities of the enterprise.

It should also be considered that production also includes activity of an auxiliary (subsidiary) productions the costs of which are also considered to be transformational.

Beside the operational activity company may be engaged in financial activity, which leads to changes in the size and composition of own and borrowed capital of the enterprise. In the process of financial activity of the enterprise, borrowed funds are used to conduct other activities. Principal loan amount reimbursement is not recognised as an expense. However, interest paid and other borrowing costs incurred are recognized as expenses. That is, the cost of financial activity is a fee for the use of the resources involved, their volume depends on the situation on the credit market or capital markets, which is largely the result of the market factors.

Acquisition and marketing of non-current assets and financial investments by the enterprise, which is not an integral part of cash equivalents, is the basis of investment activity. The incurred expenses of this type of activity are primarily due to conjuncture changes, results of the activities of economic entities, whose equity instruments are the objects of investment and also correspond to the nature of the transformation costs.

Within the limits of the enterprise activity of the transaction costs include the cost of searching for information (buyers and sellers), which takes time, effort and resources in markets with asymmetric information, which is the result of incompleteness and imperfection of the information [6, p. 673], costs incurred when individuals exchange property rights for economic assets and secure their property rights, costs associated with providing access to resources [7].

Not all actual transaction costs incurred can be investigated by accounting. In the scientific literature, such category of transaction expenses as illegal, associated with the "price beyond the legality" [8]. Typically, these costs are part of the illegal, shadow economy, and above all, these are bribes, kickbacks, etc., respectively, these costs are not officially recorded. Also, the implicit costs (losses) can not be investigated by the accounting method, which are determined by an alternative principle and arise in the exchange of property rights [9].

That is why this article only reveals methodological features of some transaction expenses, those are possible to detect and estimate through accounting, the ones actually incurred costs recorded in primary documents and disclosed in the financial statements, but are not classified as transaction costs. 


\section{ФIHАНСИ. БАНКІВСЬКА СПРАВА}

Taking into account the scientific achievement of the institutional theory of transaction expenses study and the accounting theory provisions, several features of transaction costs of economic entities can be distinguish (Tab. 1).

\section{Transaction expenses signs of economic entities}

Table 1

\begin{tabular}{|c|c|c|}
\hline \# & Sign & Characteristics \\
\hline 1 & $\begin{array}{l}\text { Assets and rights } \\
\text { to exchange on the } \\
\text { market }\end{array}$ & $\begin{array}{l}\text { Transaction costs of exchange include expenses incurred by the entity in the } \\
\text { process of market research, negotiation, conclusion of contracts and their } \\
\text { monitoring, insurance of purchased goods or sold products (works, services), } \\
\text { financial expenses }\end{array}$ \\
\hline 2 & $\begin{array}{l}\text { Providing access } \\
\text { to resources and } \\
\text { markets }\end{array}$ & $\begin{array}{l}\text { This group includes transaction expenses, the emergence of which is caused by } \\
\text { the economic entitie organisational activitiy. Costs of such activity not always } \\
\text { ending with exchange or as a result another exchange regime may occur non- } \\
\text { existent on the market. Transaction expenses that provide access to resources } \\
\text { and markets include research expenses (access to information resources), } \\
\text { communication, membership fees in associations, charitable contributions and } \\
\text { sponsorship, representative expenses. }\end{array}$ \\
\hline 3 & $\begin{array}{l}\text { Law enforcement } \\
\text { and administration }\end{array}$ & $\begin{array}{l}\text { This group includes management costs of a business entity, entry ino and exit } \\
\text { from the market, implemented in compliance with the legislation on registration of } \\
\text { legal entities, licensing of certain types of activities and obtaining permits, etc. } \\
\text { Also, this group includes transaction expenses related to the implementation of } \\
\text { tax, civil, economic, and pension legislation, in particular, the costs of paying } \\
\text { taxes and compulsory payments, accounting and tax, financial and statistical } \\
\text { reports. }\end{array}$ \\
\hline 4 & $\begin{array}{l}\text { Prejudice of } \\
\text { opportunistic } \\
\text { behavior of } \\
\text { economic entities }\end{array}$ & $\begin{array}{l}\text { Opportunistic behavior is possible in all areas of the subject's business, both } \\
\text { externally and internally. Thus, against the opportunistic behavior of the economic } \\
\text { entitie's employees transaction expenses would be costs to maintaine quality } \\
\text { control and internal security departments. } \\
\text { And against external - security upkeep or involvement of specialised units, } \\
\text { property insurance against theft or intentional damage. Based on this costs of } \\
\text { information security, counteraction to raider attacks, proactive competitive } \\
\text { measures, etc. are recognized. }\end{array}$ \\
\hline 5 & $\begin{array}{l}\text { Ensuring the } \\
\text { protection of rights } \\
\text { and interests }\end{array}$ & $\begin{array}{l}\text { Protection of economic entity's legitimate rights and interests through the } \\
\text { opportunistic behavior is connected not only with the process of exchange but } \\
\text { also with other areas of activity and is the result of its rights and freedoms. First of } \\
\text { all, based on this, transaction expenses for legal support, for court disputes and } \\
\text { execution of their decisions, for attracting specialised agencies to work with } \\
\text { debtors (collecting firms) and other similar expenses are recognized. }\end{array}$ \\
\hline
\end{tabular}

As follows the recognised expenses of an economic entity are classified as transactional in the event of one or more characteristics match, such as: the process of exchange of assets and rights, access to resources and markets, law enforcement and administration, the prevention of opportunistic behavior of economic agents, protection rights and interests [10].

In the classification of economic entity expenses, defined in P(C)BO 16 "Expenses" [5], separately stands out group of expenses, which is directly related to ensuring the process of exchange of assets and rights, information disclosed in separate articles of the Report on Financial results (Consolidated Income Statement) (Form No. 2) are the costs of sales and financial expenses.

Expenses that are of a general economic nature and are aimed at maintaining and managing an enterprise constitute a separate classification group, information on which is disclosed under the heading "Administrative expenses". They are not as homogeneous as the costs of sales, which requires an individual analysis of the components of this group (Tab. 2).

The analysis provides grounds for asserting that expenditures of general economic nature, aimed at maintaining and managing an enterprise and included in administrative expenses, are transaction expenses. 


\section{ФIHАНСИ. БАНКІВСЬКА СПРАВА}

The dominant feature of the administrative costs recognised as transaction expenses is "Enforcement of law and administration", which is associated with a high level of normative regulation of economic activity [11]. The highest level of regulations have economic entities which organisational and legal form involves the capital attraction - business associations, respectively, they carry transaction costs of business forms, such as general corporate expenses (organisational, for holding annual fees, etc.), that are not common characteristics of business entities of other organisational and legal forms.

Table 2

\section{Comparison of administrative expenses with transaction expenses}

\begin{tabular}{|c|c|}
\hline Administrative costs & Features of Transaction expense \\
\hline $\begin{array}{l}\text { 1. General corporate expenses (organizational, to } \\
\text { hold annual meetings, representative, etc.) }\end{array}$ & $\begin{array}{l}\text { Enforcement of law and administration } \\
\text { Providing access to resources and markets }\end{array}$ \\
\hline $\begin{array}{l}\text { 2. Business trip expenses and maintenance of } \\
\text { business management and other general } \\
\text { business staff }\end{array}$ & $\begin{array}{l}\text { Ensuring the exchange process } \\
\text { Providing access to resources and markets } \\
\text { Enforcement of law and administration } \\
\text { Prejudice opportunistic behavior } \\
\text { Ensuring the protection of rights and interests }\end{array}$ \\
\hline $\begin{array}{l}\text { 3. Costs of maintenance of fixed assets, other } \\
\text { non-current assets of general use and } \\
\text { depreciation of intangible assets of general } \\
\text { economic use }\end{array}$ & $\begin{array}{l}\text { Ensuring the exchange process } \\
\text { Providing access to resources and markets } \\
\text { Enforcement of law and administration } \\
\text { Ensuring the protection of rights and interests } \\
\text { Prejudice opportunistic behavior }\end{array}$ \\
\hline $\begin{array}{l}\text { 4. Professional services fees (legal, accounting, } \\
\text { property valuation etc.) }\end{array}$ & $\begin{array}{l}\text { Ensuring the exchange process } \\
\text { Providing access to resources and markets } \\
\text { Enforcement of law and administration } \\
\text { Prejudice opportunistic behavior } \\
\text { Ensuring the protection of rights and interests }\end{array}$ \\
\hline 5. Communication costs & Providing access to resources and markets \\
\hline 6. Costs for settling disputes in the judiciary & $\begin{array}{l}\text { Enforcement of law and administration } \\
\text { Ensuring the protection of rights and interests }\end{array}$ \\
\hline $\begin{array}{l}\text { 7. Taxes, fees and other statutory mandatory } \\
\text { payments }\end{array}$ & Enforcement of law and administration \\
\hline $\begin{array}{l}\text { 8. Fee for cash management services, banking } \\
\text { services, expenses related to currency purchase } \\
\text { and sale }\end{array}$ & $\begin{array}{l}\text { Enforcement of law and administration } \\
\text { Providing access to resources and markets }\end{array}$ \\
\hline $\begin{array}{l}\text { 9. Other expenses of general purpose intended } \\
\text { for maintenance and management of the } \\
\text { enterprise }\end{array}$ & $\begin{array}{l}\text { Ensuring the exchange process } \\
\text { Providing access to resources and markets } \\
\text { Enforcement of law and administration } \\
\text { Prejudice opportunistic behavior } \\
\text { Ensuring the protection of rights and interests }\end{array}$ \\
\hline
\end{tabular}

Source: created by the authors on the basis of [5]

Separately should be recognised transaction costs of payment and cash services and other banking services, as well as costs associated with the purchase and sale of currency. In our opinion, the incurred costs of banking services for cash and settlement services is due to the institutional model of payments.

Introduction of another model of settlement, an alternative to mandatory non-cash payments, will lead to a banking services cost reduction.

Therefore, these costs incurrence is due to the need for business entities to comply the legislation, so they correspond with the signs of the transaction expenses.

Costs associated with currency purchase and sale for economic entities that provide currency conversion services and exchange process accordingly, are transaction expenses-related.

When include other expenses to an administrative costs, it is necessary to consider not only their general purpose, but also compliance with the transaction costs features. 


\section{ФIHАНСИ. БАНКІВСЬКА СПРАВА}

The next group of expenses to be investigated is other operating expenses. However, this group includes costs that are not related to a particular area of the economic entity's business, as a result part of them are related to the transformation of assets, as well as those that can be recognised as transaction expenses-related, as evidenced by the results of the analysis of these costs (Tab. 3).

Table 3

Comparison of other operating expenses with features of transaction expenses

\begin{tabular}{|l|l|}
\hline \multicolumn{1}{|c|}{ Other operating expenses } & \multicolumn{1}{|c|}{ Features of Transaction expenses } \\
\hline 1. Research and development costs & Does not match \\
\hline $\begin{array}{l}\text { 2. Cost of sold inventories } \\
\text { 3. The amount of bad debts and deductions to the reserve of } \\
\text { doubtful debts }\end{array}$ & $\begin{array}{l}\text { Does not match } \\
\text { Prejudice opportunistic behavior }\end{array}$ \\
\hline $\begin{array}{l}\text { 4. Loss from operating exchange rate difference (i.e changes } \\
\text { in exchange rates on operations, assets and liabilities related } \\
\text { to the operating activities of the enterprise) }\end{array}$ & Does not match \\
\hline 5. Losses from impairment of inventories & Does not match \\
\hline $\begin{array}{l}\text { 6. Shortages and losses from damage to property } \\
\text { Complies about costs that of } \\
\text { opportunistic behavior. } \\
\text { Does not complies for expenses that are the } \\
\text { result of an accident }\end{array}$ \\
\hline $\begin{array}{l}\text { 7. Recognised fines and penalties } \\
\text { maintenance the social and cultural purpose objects }\end{array}$ & $\begin{array}{l}\text { Ensuring the exchange process } \\
\text { Prejudice opportunistic behavior }\end{array}$ \\
\hline $\begin{array}{l}\text { 9. Costs of initial recognition and changes in the value of } \\
\text { assets that are accounted for at fair value }\end{array}$ & Does not match \\
\hline $\begin{array}{l}\text { 10. Cost of foreign currency } \\
\text { purchase and sale }\end{array}$ & Ensuring the exchange process \\
\hline
\end{tabular}

Source: created by the authors on the basis of [P(C)BO 16 "Costs"]

Analysis results show that considered classification group - other operating costs - can not be fully included in the transaction expenses. Only part of the expenses can be unambiguously classified as transaction expenses. While classifying the costs of this group, individual analysis of the actual costs incurred needed for compliance with transaction expenses. Significant components of transaction expenses are taxes, some of which are accounted for in administrative expenses.

Income tax presented in a separate article. Assigning social payments to transaction expenses is still a discussion matter [12].

Such costs can be considered both as payments to employees and as transaction expenses. In favor of the second some arguments can be provided.

Firstly, such expenses are not determined by market factors, such as wages and employee reward systemb, but are the result of an institutional system; secondly, based on the essence of compulsory state pension insurance solidarity system, in which all funds transferred by business entities and insured persons to the Pension Fund of Ukraine are immediately paid to current pensioners, deductions for social measures are fiscal in nature.

Taking into consideration given above we believe that contributions for social measures should be recognized as transaction expenses.

Therefore, the transaction expenses are fully accounted costs that, according to the existing classification, include administrative expenses, financial expenses, sales costs, expenses on income tax and social charges deductions, as well as individual expenses that fall into the other operating expenses category.

Some transaction expenses do not include these groups (Tab.4).

Part of the above mentioned expenses in Table 4 are reflected in capital investments and include in the initial cost of fixed assets, intangible assets, long-term biological assets and investment property, 


\section{ФІНАНСИ. БАНКІВСЬКА СПРАВА}

and part of the accounts for inventories and current biological assets, which increases their initial value.

Table 4

Other transaction expenses groups

\begin{tabular}{|c|l|}
\hline$\#$ & \multicolumn{1}{|c|}{ Transaction expenses groups } \\
\hline 1 & $\begin{array}{l}\text { registration fees, state duties and similar payments made in connection with the acquisition the rights to } \\
\text { fixed assets, intangible assets, long-term biological assets and investment real estate pack }\end{array}$ \\
\hline 2 & $\begin{array}{l}\text { import duty on the acquisition of fixed assets, intangible assets, investment property, biological assets } \\
\text { and stocks; }\end{array}$ \\
\hline 3 & $\begin{array}{l}\text { the amount of indirect taxes in connection with the acquisition of fixed assets, intangible assets, } \\
\text { investment property, biological assets and stocks (if they are not reimbursed); }\end{array}$ \\
\hline 4 & insurance costs, legal services, commission fees related to the acquisition of these assets; \\
\hline 5 & $\begin{array}{l}\text { other transaction costs that are directly related to the acquisition and bringing of the aforementioned } \\
\text { assets to a condition in which they are suitable for use with the intended purpose. }\end{array}$ \\
\hline
\end{tabular}

Source: systematized by the authors taking into account $[13 ; 14]$

Conclusions. The main factors in the transaction expenses incurrence are the uncertainty of the economic entity behavior, the implementation of the established social norms, ensuring the realisation and protection of the rights and interests of the subjects of economic relations and society.

Accounting as a method of research of socio-economic processes and phenomena can provide the study of only those costs that appear in its subject at the level of the economic entity or budget. Accordingly, the object of accounting is only those transaction expenses that are the result of business transactions and are recorded in primary documents and the implementation of which does not contradict the law (formal rules).

Transaction expenses incurrence are not intended to generate income, therefore, entities should include them in the financial result at the time of occurrence.

Otherwise, this will lead to a diversion from the economic entity's resources circulation of business in connection with the capitalisation of transaction expensess in the value of non-current assets and, accordingly, their reimbursement over several periods, which is economically unjustified and leads to additional losses of economic entities through inefficiency of the institutional system.

In connection with the above, it is necessary to review formation order of the initial value of assets in order to prevent the inclusion of transaction expenses associated with the acquisition, to their original cost, and to attribute them to administrative costs, capitalisation of financial costs to carry out on a voluntary basis.

However, for the implementation of these proposals, the professional community should be aware of them at the international level, whereas only domestic practice will lead to a violation of the common methodological approaches to assets cost formation.

The reasons for incurred transaction expenses are predetermined by institutional factors, but their volume is formed taking into account market factors. The amount of financial costs, as well as the cost of sales, depends on the market conditions for the corresponding resources and services (work) in competitive markets. Administrative expenses and expenses on income tax and deductions for social measures depend to a large extent on the performance of economic entities, which in turn depends on the overall economic situation.

\section{References}

1. Auzan, A. A. (2005). Institutsionalnaia ekonomika: novaia institutsionalnaia ekonomicheskaia teoriia [Institutional Economics: A New Institutional Economic Theory]. Moskow: INFRA-M [in Russian].

2. Williamson, O.E. (2016). The transaction cost economics project: origins, evolution, utilization. The Elgar Companion to Ronald $\mathrm{H}$. Coase. Retrieved from https://books.google.com.ua/books?id=SnKNCwAAQBAJ\&pr intsec=frontcover\&hl=uk\#v=onepage\&q\&f=false [in English].

3. Chukhno, A. A., Leonenko, P. M. Yukhimenko, P. I.

\section{Література}

1. Аузан, А. А. Институциональная экономика: новая институциональная экономическая теория: учебник / под общ. ред А. А. Аузана. - М. : ИНФРА-М, 2005. - 416 c.

2. Williamson, O. E. (2016). The transaction cost economics project: origins, evolution, utilization. The Elgar Companion to Ronald H. Coase, 34. Режим доступу: https://books.google.com.ua/books?id=SnKNCwAAQBAJ\&pri ntsec $=$ frontcover $\& h l=u k \# v=$ onepage $\& q \& f=$ false.

3. Чухно, А. А. Інституціонально-інформаційна 


\section{ФIНАНСИ. БАНКІВСЬКА СПРАВА}

(2010). Institutsionalno-informatsiina ekonomika [Institutional and informational economy]. Kyiv: Znannia [in Ukrainian].

4. Koenig, D. R. (2012). Governance Reimagined: Organizational Design, Risk, and Value Creation. John Wiley \& Sons [in English].

5. Nakaz Ministerstvf finansiv Ukrainy Pro zatverdzhennia Polozhennia (standartu) bukhhalterskoho obliku 16 "Vytraty»: vid 31.12.1999, №318 [Order of the Ministry of Finance of Ukraine on Regulation (Standard) of Accounting 16 "Expenses": from 31.12.1999, №318]. Retrieved from http://zakon3.rada.gov.ua/laws/show/z002700 [in Ukrainian].

6. Mocherny, S. V. (2002). Ekonomichna entsiklopediia [Economic Encyclopedia]. (Vol. 3). Kyiv [in Ukrainian].

7. Eggertsson, T. (2001). Ekonomicheskoe povedenie $i$ instituty [Economic Behavior and Institutions]. Akademiia narodnogo khoziaistva pri Pravitelstve RF, Moskow: Delo [in Russian].

8. Barsukova, S. Yu. (2000). Transaktsionnye izderzhki vkhozhdeniia na rynok predpriiatii malogo biznesa [Transaction costs of entering the market of small businesses]. Problemy progonozirovaniia - Problems of forecasting, 1, 108-119 [in Russian].

9. Arkhiiereiev, S. I. (2002). Transaktsiini vytraty v umovakh rinkovoi transformatsii [Transaction costs in a market transformation]. Extended abstract of candidate's thesis. Khariv [in Ukrainian].

10. Yushchak, Zh. M. (2009). Pidkhody do klasifikatsii transaktsiinykh vytrat dlia potreb bukhhalterskoho obliku [Approaches to the classification of transaction costs for accounting]. Problemi teoriï ta metodologiï bukhgalterskogo obliku, kontroliu i analizu. Mizhnarodnii zbirnik naukovikh pratc. Seriia: Bukhgalterskii oblik, kontrol $i$ analiz - Problems of the theory and methodology of accounting, control and analysis. International collection of scientific papers. Series: Accounting, control and analysis, 2(14), 235-245 [in Ukrainian].

11. Hsieh, C. T., Hsieh, C. T., Huang, H. C., Huang, H. C., Lee, W. L., \& Lee, W. L. (2016). Using transaction cost economics to explain open innovation in start-ups. Management Decision, 54(9), 2133-2156 [in English].

12. Shyhun, M. M. (2016) Metodychni pidkhody do bukhhalterskoho obliku transaktsiinykh vytrat [Methodological approaches to accounting transaction costs]. Mizhnarodnyi zbirnyk naukovykh prats - International collection of scientific works, 3(15), 30-35 [in Ukrainian].

13. Kyriienko, A., Ivanova, N. (2016). Problems of Empirical Estimation of Transaction Costs. Scientific Papers NaUKMA. Economics, 172, 44-48 [in English].

14. Kantsurov, O. O. (2014). Metodolohichni zasady bukhhalterskoho obliku transaktsiynykh vytrat [Methodological principles of accounting for transaction costs]. Efektyvna ekonomika - Effective economy, 10. Retrieved http://www.economy.nayka.com.ua/?op=1\&z=3432 Ukrainian]. економіка: підручник / А. А. Чухно, П. М. Леоненко, П. І. Юхименко / за ред. акад. НАН України А. А. Чухна. - К. : Вид-во "Знання", 2010. - 687 с.

4. Governance Reimagined: Organizational Design, Risk, and Value Creation - Режим доступу: http://nobelprize.org/nobel_prizes/economics/laureates/2009/ ecoadv09.pdf.

5. Про затвердження Положення (стандарту) бухгалтерського обліку 16 «Витрати»: Наказ Міністерства фінансів України № 318 від 31.12 .99 р. зі змінами [Електронний ресурс]. - Режим доступу: http://zakon3.rada.gov.ua/laws/show/z0027-00.

6. Економічна енциклопедія: В 3-х т. - Т. 3. - К. 2002. - 952 c.

7. Эггертссон, Т. Экономическое поведение и институты / Т. Эггертссон.; пер. с англ. М. Я. Каждан ; науч. ред. пер. А. Н. Нестеренко; Академия народного хозяйства при Правительстве РФ. - М. : Дело, 2001. $407 \mathrm{c}$

8. Барсукова, С. Ю. Трансакционные издержки вхождения на рынок предприятий малого бизнеса / С. Ю. Барсукова // Проблемы прогонозирования. - 2000. - № 1 - C. $108-119$.

9. Архієреєв, С. І. Трансакційні витрати в умовах ринкової трансфрормації: автореф. дис. на здобуття наук. ступеня д-ра екон. наук: спец. 08.01.01 / С. І. Архієреєв. -X., 2002. - 32c.

10. Ющак, Ж. М. Підходи до класифрікації трансакційних витрат для потреб бухгалтерського обліку / ж. М. Ющак // Проблеми теорії та методології бухгалтерського обліку, контролю і аналізу. - 2009. - № 2 (14). - C. 235-245.

11. Hsieh, C. T., Hsieh, C. T., Huang, H. C., Huang, H. C., Lee, W. L., \& Lee, W. L. (2016). Using transaction cost economics to explain open innovation in start-ups. Management Decision, 54 (9), 2133-2156.

12. Шигун, М. М. Методичні підходи до бухгалтерського обліку трансакційних витрат / М. М. Шигун // Міжнар. зб. наук. праць ЖДТУ. - Вип. 3 (15). 2009. - C. 30-35.

13. Kyriienko, A., \& Ivanova, N. (2016). Problems of Empirical Estimation of Transaction Costs. Scientific Papers NaUKMA. Economics, 172, 44-48.

Канцуров, О. О. Методологічні засади бухгалтерського обліку трансакційних витрат [Електронний ресурс] / О. О. Канцуров // Ефективна економіка. - 2014. - № 10. - Режим доступу: http://www.economy.nayka.com.ua/?op=1\&z=3432.

Received for publication 15.05.2017

Бібліографічний опис для цитування :

Nitsenko, V. S. Accounting of transaction expenses of economic entities / V. S. Nitsenko, V. S. Mukoviz, O. M. Sharapa // Науковий вісник Полісся. - 2017. - № 4 (12). Ч. 2. - С. 71-78. 